\title{
Liability threshold for damages in public procurement: the EFTA Court's Fosen-Linjen saga
}

\author{
Albert Sanchez-Graells* \\ University of Bristol
}

\begin{abstract}
In this case comment, I explore the two EFTA Court Judgments in the Fosen-Linjen saga and their opposing views on the interaction between EU/EEA rules on procurement remedies and the more general principle of state liability for breaches of EU/EEA law. I review the case law of the Court of Justice of the European Union and, in particular, the perceived inconsistencies between the two 2010 judgments in Strabag and Spijker, which featured very prominently in the legal arguments submitted to the EFTA Court in both Fosen-Linjen cases. I also use the benchmark of the UK Supreme Court's Nuclear Decommissioning Authority judgment to support the view that Spijker reflects the correct understanding of EU/EEA law and that there should be no further debate about it. I submit that the Court of Justice of the European Union would be well-advised to (re)confirm the position enshrined in Spijker at the earliest opportunity, to avoid any perpetuation of this debate in the context of EU/EEA public procurement law.
\end{abstract}

Keywords: public procurement; damages; liability threshold; Fosen-Linjen; Nuclear Decommissioning Authority; EFTA Court; CJEU; UK Supreme Court; Spijker; Strabag

\section{Introduction}

n 1 August 2019, the European Free Trade Association's Court (EFTA Court) confirmed in Fosen-Linjen $I I^{1}$ that the threshold for damages claims for breaches of EU/European Economic Area (EEA) public procurement law is that of a 'sufficiently

* Professor of Economic Law, University of Bristol Law School. This case note builds on the previous discussion in the paper 'You Can't Be Serious: Critical Reflections on the Liability Threshold for Damages Claims for Breach of EU Public Procurement Law after the EFTA Court's Fosen-Linjen Opinion' (2018) 1(1) Nordic Journal of European Law 1-23, which discussed the Fosen-Linjen I judgment in detail. I am grateful to Prof Roberto Caranta, Dr Roxana Vornicu and the contributors to a special issue of the European Procurement and Public Private Partnership Law Review for further discussions on the Fosen-Linjen saga. A complementary discussion of the saga from the perspective of the minimum harmonisation carried out by the Remedies Directive can be found there. The standard disclaimer applies. Further comments welcome: a.sanchez-graells@bristol.ac.uk.

1 Judgment of 1 August 2019 in Fosen-Linjen AS, supported by Naringslivets Hovedorganisasjon (NHO) v AtB AS (E7/18) ('Fosen-Linjen II') < https://eftacourt.int/download/7-18-judgment/?wpdmdl=6235>. 
serious breach' of the applicable rules and that the Remedies Directive 2 'does not require that any breach of the rules governing public procurement in itself is sufficient to award damages'. 3 This judgment resulted from a request for an advisory opinion from the Supreme Court of Norway, which harboured doubts as to the adequacy of the earlier EFTA Court Judgment of 31 October 2017 in Fosen-Linjen $I,{ }^{4}$ where the Court had taken the diametrically opposed view that a 'simple breach of public procurement law is in itself sufficient to trigger the liability of the contracting authority'. ${ }^{5}$ This remarkable U-turn by the EFTA Court has raised significant controversy, not least because both advisory opinions were issued in the context of the same underlying litigation.

This case note considers the systematic interpretation issues that underpin the FosenLinjen saga and, in particular, the contested relationship between the system of remedies for the enforcement of EU/EEA public procurement law and the more general principle of state liability for breaches of EU/EEA law (i.e. the so-called Francovich doctrine). ${ }^{6}$ Such interpretive issues stem from the perceived contradiction between two 2010 judgments of the Court of Justice of the European Union (CJEU) in Strabag ${ }^{7}$ and Spijker. ${ }^{8}$ Remarkably, this had already been addressed in 2017 by the UK Supreme Court in Nuclear Decommissioning Authority v EnergySolutions, ${ }^{9}$ which reached the same position as Fosen-Linjen II.

\section{The facts}

In Fosen-Linjen, the contracting authority had tendered a contract for the provision of ferry services. ${ }^{10}$ The award criteria were 'price' (50 per cent), 'environment' ( 25 per cent) and 'quality' (25 per cent). ${ }^{11}$ Remarkably, the evaluation of the award criterion 'environment' was based on the tenderers' specification of fuel oil consumption for the offered ferries, but tenderers were not required to demonstrate how the fuel oil consumption value was calculated or to state the assumptions upon which the calculations were based. ${ }^{12}$

After being judicially challenged on this approach, the contracting authority eventually acknowledged that it had failed to establish a reasonable basis for evaluation and that it had committed an error by not verifying the reasonableness of the tenders, which could be in violation of the applicable EU/EEA procurement rules. ${ }^{13}$ The contracting authority cancelled the tender and entered into an emergency contract for the short-term provision of ferry services, with a view to retendering the longer-term contract. The

2 Directive 89/665/EEC on the coordination of the laws, regulations and administrative provisions relating to the application of review procedures to the award of public supply and public works contracts [1989] OJ L395/33, as amended by Directive 92/50/EEC [1992] OJ L 209/1, and by Directive 2007/66/EC [2007] L 335/31 (hereinafter, the 'Remedies Directive').

3 Fosen-Linjen II (n 1) para 121.

4 Judgment of 31 October 2017 in Fosen-Linjen AS v AtB AS (E-16/16) ('Fosen-Linjen I') <https://eftacourt.int/wp-content/uploads/2019/01/16_16_Judgment_EN.pdf>.

5 Ibid para 82.

6 Following the judgments of 19 November 1991, Francovich and Others, C-6/90 and C-9/90, EU:C:1991:428, and of 5 March 1996, Brasserie du Pêcheur and Factortame, C-46/93 and C-48/93, EU:C:1996:79.

7 Judgment of 30 September 2010, Strabag and Others, C-314/09, EU:C:2010:567.

8 Judgment of 9 December 2010, Combinatie Spijker Infrabouw-De Jonge Konstruktie and Others, C-568/08, EU:C:2010:751.

9 Nuclear Decommissioning Authority v Energy Solutions EU Ltd (now ATK Energy Ltd) [2017] UKSC 34.

10 Fosen-Linjen I (n 4) para 19.

11 Ibid para 23.

12 Ibid para 25.

13 As interpreted in the Judgment of 4 December 2003, EVN and Wiestrom, C-448/01, EU:C:2003:651. 
disappointed tenderer Fosen-Linjen did not submit a tender in the new procedure. ${ }^{14}$ Instead, Fosen-Linjen sued the contracting authority in damages for positive contract interest (loss of profit - lucrum cessans) or, in the alternative, for negative contract interest (costs of bidding - damnum emergens). ${ }^{15}$

The first instance court rejected the claim for damages with regard to both the negative and the positive contract interest sought, ${ }^{16}$ despite establishing that the contracting authority had failed to meet its documentary obligations. ${ }^{17}$ The Court of Appeal identified a legal issue requiring the interpretation of the Remedies Directive and, in particular, Article $2(1)(c)$, which requires member states to grant their review bodies or courts the power to 'award damages to persons harmed by an infringement' of EU public procurement rules. The Court of Appeal addressed six questions on the interpretation of that provision and its interaction with the Norwegian domestic rules on damages to the EFTA Court.

The relevant questions sought clarification on how to apply the general requirement for a 'substantial breach' of EU public procurement law in the context of claims for damages, as the referring court expressed its difficulty in reconciling the CJEU judgments in Commission v Portugall ${ }^{18}$ and Strabag with the same court's judgment in Spijker. ${ }^{19}$ The questions and sub-questions thus concerned whether liability under the Remedies Directive was conditional: (i) upon the contracting authority having deviated markedly from a justifiable course of action, (ii) upon it having incurred a material error that justified a finding of culpability under a general assessment; or (iii) upon it having incurred in an inexcusable 'material, gross and obvious error' (question 1), or whether liability could be triggered under a test of 'sufficiently qualified breach' where the contracting authority was left with no discretion as to how to interpret or apply the infringed substantive rule (question 2). ${ }^{20}$

The EFTA Court delivered its advisory opinion in Fosen-Linjen I (discussed in detail below at 2.1), where it essentially found that a:

... simple breach of public procurement law is in itself sufficient to trigger the liability of the contracting authority to compensate the person harmed for the damage incurred, pursuant to Article 2(1)(c) of the Remedies Directive, provided that the other conditions for the award of damages are met including, in particular, the existence of a causal link. ${ }^{21}$

This was contested in the context of a further appeal to the Norwegian Supreme Court, after the Court of Appeal interpreted the EFTA Court's judgment in Fosen-Linjen I to the effect that any breach of public procurement law is in itself sufficient for there to be a basis of liability for the 'positive contract interest', but decided not to follow it because the Court of Appeal considered that there are diverging views on this issue throughout the EEA, and that the EFTA Court's judgment in Fosen-Linjen I 'does not appear to be clearly correct' on that point. On that basis, the Court of Appeal decided that damages for the 'positive contract interest' are contingent on there being a sufficiently serious breach, as established by the Supreme Court of Norway in its earlier case law. The Court

14 Fosen-Linjen I (n 4) para 31.

15 Ibid para 32.

16 Ibid para 33.

17 Ibid para 34.

18 Judgment of 14 October 2004, Commission v Portugal, C-275/03, EU:C:2004:632 (not available in English).

19 Fosen-Linjen I (n 4) para 37.

20 Ibid para 36.

21 Ibid para 82. 
of Appeal considered that this was in line not only with the CJEU judgment in Spijker, but also with the Francovich doctrine. ${ }^{22}$

The Supreme Court of Norway decided to request a fresh advisory opinion from the EFTA Court. It referred a single question, asking whether Article 2(1)(c) of the Remedies Directive required that any breach of the rules governing public procurement in itself is sufficient for there to be a basis of liability for positive contract interest. ${ }^{23}$

The EFTA Court delivered its advisory opinion in Fosen-Linjen II (discussed in detail below at 2.2), where it found that: 'Article 2(1)(c) of the Remedies Directive does not require that any breach of the rules governing public procurement in itself is sufficient to award damages for the loss of profit to persons harmed by an infringement of EEA public procurement rules. 24

At the time of writing (17 September 2019), the final decision of the Supreme Court of Norway is pending. However, the outcome of the case is not relevant for the purposes of our discussion.

\section{The judgments}

\subsection{FOSEN-LINJEN I}

In Fosen-Linjen I, the EFTA Court decided to group questions 1 and 2 and to carry out a joint assessment of the threshold and conditions for liability in damages for breach of EU/EEA procurement law. ${ }^{25}$ After revisiting the goals of the then applicable EU/EEA rules (Directive 2004/18/EC), ${ }^{26}$ the EFTA Court engaged in an analysis of the goals of the Remedies Directive.

The Court stressed that the Directive aims at 'providing adequate remedies that ensure compliance with the relevant EEA provisions on public contracts', ${ }^{27}$ and that another of its fundamental objectives is 'to create the framework conditions under which tenderers can seek remedies in the context of public procurement procedures, in a way that is as uniform as possible for all undertakings active on the internal market. Thereby ... equal conditions shall be secured. 28

The Court then proceeded to establish that Article 2(1)(c) of the Remedies Directive states that the measures taken concerning such review procedures must include provision for powers to award damages to those harmed by an infringement of public procurement law, but that neither such provision nor any other provisions of the Remedies Directive lay down any conditions for the award of damages as a remedy in the field of public procurement. ${ }^{29}$ Indeed, the Remedies Directive in no way indicates that the infringement of the public procurement legislation liable to give rise to a right to damages in favour of the person harmed should have specific features. ${ }^{30}$ In the absence of such detailed

22 Fosen-Linjen II (n 1) para 32.

23 Ibid para 36.

24 Ibid para 121.

25 Fosen-Linjen I (n 4) para 48.

26 Directive 2004/18/EC of the European Parliament and of the Council of 31 March 2004 on the coordination of procedures for the award of public works contracts, public supply contracts and public service contracts [2004] OJ L134/114. Fosen-Linjen I (n 4) paras 61-65.

27 Fosen-Linjen I (n 4) para 66.

28 Ibid para 67.

29 Ibid para 69.

30 Ibid para 71. 
conditions, the EFTA Court found that it is for the legal order of each EEA state to determine the criteria on the basis of which harm caused by an infringement of EEA law on the award of public contracts must be assessed, as long as it complies with the principles of equivalence and effectiveness. ${ }^{31}$

The EFTA Court then restated relevant CJEU case law to the effect that the remedy of damages provided for in Article 2(1)(c) of the Remedies Directive can only constitute a procedural alternative compatible with the principle of effectiveness where the possibility of damages is no more dependent on a finding that the contracting authority is at fault than the other legal remedies provided for in Article 2(1) - such as setting aside unlawful decisions. ${ }^{32}$ Article 2(1)(c) of the Remedies Directive therefore precludes national legislation which makes the right to damages for an infringement of public procurement law conditional on that infringement being culpable. ${ }^{33}$ On the basis of this premise, and without much more by way of an explanation, the EFTA Court proceeded to argue that:

... [t] he same must apply where there exists a general exclusion or a limitation of the remedy of damages to only specific cases. This would be the case, for example, if only breaches of a certain gravity would be considered sufficient to trigger the contracting authority's liability, whereas minor breaches would allow the contracting authority to incur no liability. ${ }^{34}$

The EFTA Court sought to strengthen this reasoning by arguing that 'a rule requiring a breach of a certain type or gravity would, ultimately, substantially undermine the goal of effective and rapid judicial protection sought by the Remedies Directive. It would also interfere with the objectives pursued by EU/EEA procurement law. ${ }^{35}$ The Court added that:

... the gravity of a breach of the EEA rules on public contracts is irrelevant for the award of damages. Moreover, it is not decisive for the award of damages pursuant to Article 2(1)(c) of the Remedies Directive, whether the breach of a provision of public procurement law was due to culpability and conduct deviating markedly from a justifiable course of action, or whether it occurred on basis of a material error, or whether it is attributable to the existence of a material, gross and obvious error. ${ }^{36}$

The EFTA Court thus answered the first two questions referred by the Court of Appeals by finding that:

... the award of damages according to Article 2(1)(c) of the Remedies Directive does not depend on whether the breach of a provision of public procurement law was due to culpability and conduct deviating markedly from a justifiable course of action, or whether it occurred on basis of a material error, or whether it is attributable to the existence of a material, gross and obvious error. A simple breach of public procurement law is in itself sufficient to trigger the liability of the contracting authority to compensate the person harmed for the damage incurred, pursuant to Article 2(1)(c) of the Remedies Directive. ${ }^{37}$

31 Ibid para 70.

32 Ibid para 75, with reference to Strabag (n 7) para 39.

33 Fosen-Linjen I (n 4) para 77, also with reference to Strabag (n 7) para 45 and to Commission v Portugal (n 18) para 42.

34 Fosen-Linjen I (n 4) para 77.

35 Ibid para 79.

36 Ibid para 80.

37 Ibid para 82. 


\subsection{FOSEN-LINJEN II}

In Fosen-Linjen II, the EFTA Court was asked by the Norwegian Supreme Court to essentially revisit its earlier opinion in Fosen-Linjen I, although formally only in relation to the liability for positive contract interest. The legal issues to be determined were essentially the same. However, their framing by the EFTA Court was rather different.

While in Fosen-Linjen I the EFTA Court stressed that the Remedies Directive sought 'to create the framework conditions under which tenderers can seek remedies ... in a way that is as uniform as possible ... [and that] equal conditions shall be secured' 38 across the internal market, in Fosen-Linjen II, the Court stressed that:

... one of the aims of the Directive is to ensure that adequate procedures exist in all the Member States to permit the setting aside of decisions taken unlawfully and compensation of persons harmed by an infringement. Adequate review procedures ... must not necessarily be homogenous or identical, they must merely satisfy minimum conditions, which are required by the Directive in order to ensure compliance with EEA law ... the Remedies Directive is an instrument of minimum harmonisation. ${ }^{39}$

The EFTA Court then recovered the Fosen-Linjen I findings that 'neither Article 2(1)(c) nor any other provision of the Remedies Directive lays down specific conditions for the award of damages, which encompass specific heads of damage and the standard of liability in particular', ${ }^{40}$ and that:

... in the absence of EEA rules governing the matter, it is for the legal order of each EEA State, in accordance with the principle of the procedural autonomy of the EEA States, to determine the criteria on basis of which harm caused by an infringement of EEA law in the award of public contracts must be assessed ...41 [including] the criteria on the basis of which damage for loss of profit arising from an infringement of EEA law on the award of public contracts is determined and estimated, provided that the principles of equivalence and effectiveness are respected. ${ }^{42}$

In contrast with Fosen-Linjen I, however, in its second judgment, the EFTA Court sought to complement the gaps in the specific rules of the Remedies Directive with the general principle of state liability for breaches of EU/EEA law (the Francovich doctrine) before proceeding to assess the regulatory space left to member states. Indeed, the EFTA Court stressed that, while the standard of liability is not harmonised by the Remedies Directive:

. . . according to the principle of State liability, an EEA State may be held responsible for breaches of its obligations under EEA law when three conditions are met: firstly, the rule of law infringed must be intended to confer rights on individuals and economic operators; secondly, the breach must be sufficiently serious; and, thirdly, there must be a direct causal link between the breach of the obligation resting on the state and the damage sustained by the injured party. ${ }^{43}$

The EFTA Court then proceeded to recall that compliance with the principle of effectiveness requires, in particular, that national rules cannot subject the award of

38 Ibid para 67.

39 Fosen-Linjen II (n 1) para 109.

40 Ibid para 111.

41 Ibid para 113.

42 Ibid para 114.

43 Ibid para 117. 
damages to a finding and proof of fault or fraud. ${ }^{44}$ However, the Court also clarified that this does not mean that certain objective and subjective factors connected with the concept of fault under a national legal system cannot be relevant in the assessment of whether a particular breach is sufficiently serious. However, the obligation to make reparation for loss or damage caused to individuals cannot depend on a condition based on any concept of fault going beyond that of a sufficiently serious breach of EEA law. ${ }^{45}$ The EFTA Court also stressed that the requirement of a sufficiently serious breach as a minimum standard is considered sufficient for the purposes of safeguarding the rights of individuals. ${ }^{46}$

The EFTA Court thus answered the question referred by the Supreme Court of Norway by stating that Article 2(1)(c) of the Remedies Directive does not require that any breach of the rules governing public procurement in itself is sufficient to award damages for the loss of profit to persons harmed by an infringement of EEA public procurement rules. ${ }^{47}$

\section{Case analysis}

Although there are more differences between the two Fosen-Linjen judgments, it seems that the starkest contrast between them surrounds two interrelated issues. First, their approach to the level of harmonisation that the Remedies Directive imposes, where Fosen-Linjen I implicitly considers the Directive as requiring maximum harmonisation (i.e. equal conditions), while Fosen-Linjen II explicitly recognises the character of the Directive as an instrument of minimum harmonisation. ${ }^{48}$ Second, the relationship they envisage between the general principle of state liability for breaches of EU/EEA law and the specific system of the Remedies Directive. While Fosen-Linjen I seems to treat the rules of the Remedies Directive in complete isolation from the general principle of state liability, Fosen-Linjen II explicitly establishes the link between both sets of rules.

As mentioned in the introduction, these fundamental discrepancies between the two episodes of the Fosen-Linjen saga are reflective of broader academic discussions underpinned by a perceived inconsistency in the CJEU case law in this area and, in particular, the judgments in Strabag and Spijker, which are discussed in minute detail in both Fosen-Linjen judgments. Moreover, the exact same arguments had already been considered by the UK Supreme Court in 2017. This section looks in more detail at both issues.

\subsection{Procurement ReMEdies and State liability: UNITARY VS SEPARATION THESES}

One of the distinctive features of EU public procurement law as compared to more general EU internal market law lies in its specific enforceability through the mechanisms regulated in the Remedies Directive, of which the 'aim is to make more concrete the obligations imposed by EU law, in the hope that this will improve policing of the rules governing contracts awarded by public authorities and in consequence develop further

44 Ibid para, with reference to Fosen-Linjen I (n 4) para 75, as well as to Strabag (n 7) paras 39-40 and Commission $v$ Portugal (n 18) para 42.

45 Fosen-Linjen II (n 1) para 119.

46 Ibid para 120.

47 Ibid para 121.

48 For extended discussion from the perspective of minimum harmonisation, see A Sanchez-Graells, 'The EFTA Court's Fosen-Linjen Saga on the Liability Threshold for Damages Claims for Breach of EU Public Procurement Law: A There and Back Again Walk' (2019) European Procurement and Public Private Partnership Law Review (forthcoming) <https://ssrn.com/abstract=3455213>. 
the construction of a true internal market in this sector'. ${ }^{49}$ As we have seen, however, the relationship between the Remedies Directive and the general rules on national remedies for breaches of EU law is contested.

The existing debate about the relationship between these two regulatory mechanisms boils down to disagreements over whether the Remedies Directive should be constructed as a particularisation of the general principle of state liability under EU law (a 'unifying thesis') or whether a distinction should be made between 'a public law of torts in the form of Member State liability, and damages for breaches of specific EU legislation under the effectiveness postulate (the "separation thesis")'. ${ }^{50}$ The unifying thesis would result in the superimposition of the requirement of 'sufficiently serious breach' to the award of damages under the Remedies Directive. Conversely, the separation thesis would result in a free-standing interpretation of the liability threshold in the Remedies Directive and, possibly, in a reduction of the threshold of infringement triggering potential liability in damages for 'any infringement'. This would aim to avoid what has been considered 'the paradoxical result ... that although the remedies regime is more concrete and elaborate than in other areas of the law, the Court [of Justice] would be forced into the abstract generalities of Member State liability, rather than the specificities of the procurement sector'. ${ }^{51}$ Moreover, the separation thesis sometimes receives support on the basis that the Remedies Directive pre-dates the seminal case of Francovich, which opens up arguments about a possible divergence in the legal tests and, specifically, in the liability threshold applicable to each of these heads of claims for damages against the state.

\subsection{Perceived inconsistencies in CJEU case law}

Most of the legal arguments submitted to the EFTA Court in the Fosen-Linjen saga related to the consistency or incompatibility of the CJEU's judgments in Strabag and Spijker. I argue that any perceived inconsistencies result from an incorrect conceptualisation of the regulation of the system of procurement remedies and its interpretation by the CJEU.

A preliminary point needs to be made to stress that the interaction between the Remedies Directive and the general doctrine of state liability for breaches of EU law has been clarified by the CJEU. Indeed, this was explicitly addressed in Spijker, ${ }^{52}$ when the CJEU stated that Article 2(1)(c) of the Remedies Directive 'gives concrete expression to the principle of State liability for loss and damage caused to individuals as a result of breaches of EU law for which the State can be held responsible,. ${ }^{53}$ Moreover, the CJEU was clear that:

... as regards state liability for damage caused to individuals by infringements of EU law for which the state may be held responsible, the individuals harmed have a right to redress where the rule of EU law which has been infringed is intended to confer rights on them, the breach of that rule is sufficiently serious, and there is a direct causal link between the breach and the loss or damage sustained by the individuals. In the absence of any provision of EU law in that area, it is for the internal legal order of each member state, once those conditions have been complied with, to determine the criteria on the basis of which the damage arising from an infringement of $E U$

49 S Weatherill, 'EU Law on Public Procurement: Internal Market Law Made Better' in X Groussot, J Hettne and S Bogojevic (eds), Law and Discretion in EU Public Procurement, vol 26, Studies of the Oxford Institute of European and Comparative Law (Hart 2019) 21, at 43.

50 H Schebesta, Damages in EU Public Procurement Law (Springer 2016) 8. For extended discussion, see ibid 65-71, esp 67-68.

51 Ibid 71.

52 Spijker (n 8).

53 Ibid para 87, emphasis added. 
law on the award of public contracts must be determined and estimated, provided the principles of equivalence and effectiveness are complied with. ${ }^{54}$

There could not be a closer formulation of the unifying thesis than in Spijker, ${ }^{55}$ whereby it is clear that Article 2(1)(c) of the Remedies Directive fleshes out or particularises the doctrine of state liability for breaches of EU law in the context of public procurement. As mentioned above, some objections could be raised to the effect that, the Remedies Directive having been adopted in 1989, it could not have logically given expression to the principle of state liability for breach of EU law, as it was only formulated in Francovich in 1991. However, such objections can be dismissed on the basis of different types of arguments. A practical argument is that the Remedies Directive was revised in 2007, when the principle of state liability was already consolidated in CJEU case law, and the EU legislator did not consider it necessary to make any changes to Article 2(1)(c). A jurisprudential argument could also be used to dismiss the objection, on the basis that the CJEU does not create general principles of EU law in its case law, but rather draws from them or declares them - which logically requires their pre-existence (arguably, from the origins of the Treaties). ${ }^{56}$ Ultimately, at least from a positive perspective, the existence of the link between the general principle and the Directive could (and should) be allowed to rest on the simple fact that the CJEU has exclusive competence to carry out such interpretation ex Article 267 Treaty on the Functioning of the EU. ${ }^{57}$

Spijker is, however, not universally seen as having settled the issue of the interaction between the grounds for actions for damages under the Remedies Directive and under the state liability doctrine. The grounds for rejection of the unitary thesis are usually found in additional CJEU case law - namely, in the Strabag Judgment - which barred the possibility of subjecting the liability in damages of a contracting authority to a requirement of fault or fraud, 58 even if claimants can benefit from a rebuttable presumption of fault. ${ }^{59}$ Some authors consider the unitary thesis irreconcilable with a reading of Strabag that would require member states to ensure strict liability for breaches of EU public procurement law. However, I would argue that this conflates the aspect of objectivity of the assessment with the distinct issue of the threshold for liability (as not every objective breach is necessarily sufficiently serious and thus not every breach needs to result in liability). ${ }^{60}$

Those readings of Strabag are incorrect in that they miss the different levels of regulatory design at which Spijker (top layer) and Strabag (second layer) operate. ${ }^{61}$ In other words, Spijker establishes a link between the general principle of state liability and the Remedies Directive, which gives it concrete expression. Within this framework, Strabag (and other case law) modulates the requirements of the principles of effectiveness and equivalence that result from the higher regulatory layer. In any case, the main point of

54 Ibid para 92, emphasis added.

55 In agreement on the positive description, but criticising it normatively, see Schebesta (n 50) 65-72.

56 This is an issue that, however, exceeds the scope of this article and, consequently, will not be assessed in any detail.

57 Along the same lines, H C H Hofmann, 'The Court of Justice of the European Union and the European Administrative Space' in M W Bauer and J Trondal (eds), The Palgrave Handbook of the European Administrative System (Palgrave 2015) 301-12.

58 See also Commission v Portugal (n 18).

59 Strabag (n 7).

60 For discussion, see A Sanchez-Graells, 'Assessing the Public Administration's Intention in EU Economic Law: Chasing Ghosts or Dressing Windows?', in K A Armstrong (ed), Cambridge Yearbook of European Legal Studies 2016 vol 18 (Cambridge University Press 2016) 93-121.

61 To the same effect, see Nuclear Decommissioning Authority (n 9) per Lord Mance, at [24]. 
contention rests on what could be seen as a lex specialis understanding of the interaction between the two regulatory frameworks - i.e. a view that the general condition for there to be a 'sufficiently serious breach' of EU law under state liability is contrary to the requirement for strict liability for breaches of EU procurement law, which would have led the Remedies Directive to impose a lower triggering threshold by solely mentioning the need for an unqualified infringement as sufficient ground for damages claims (Article $2(1)(c)) .{ }^{62}$ As detailed above (section 2), the latter view was reignited by the EFTA Court in Fosen-Linjen I, but subsequently abandoned in Fosen-Linjen II. I argue that Fosen-Linjen II represents the right statement of EU law in this area, in particular in view of the minimum harmonisation carried out by the Remedies Directive, as discussed in the following section. Remarkably, this was the position that the UK Supreme Court had already reached before the Fosen-Linjen saga.

\subsection{The UK Supreme Court's VIEW}

In its Nuclear Decommissioning Authority judgment, ${ }^{63}$ the UK Supreme Court followed what I think is the correct reading of Spijker and established that it makes clear:

... that the liability of an awarding authority is to be assessed by reference to the Francovich conditions. Subject to these conditions being met... [it goes] on to make clear that the criteria for damages are to be determined and estimated by national law, with the further caveat that the general principles of equivalence and effectiveness must also be met ... Finally, [it] summarises what has gone before, repeating the need to satisfy the Francovich conditions. ${ }^{64}$

More importantly, the UK Supreme Court considered that:

... there is . . very clear authority of the Court of Justice confirming that the liability of a contracting authority under the Remedies Directive for the breach of the [public procurement rules] ... is in particular only required to exist where the minimum Francovich conditions are met, although it is open to States in their domestic law to introduce wider liability free of those conditions. ${ }^{65}$

Therefore, along the same lines of Fosen-Linjen II, the UK Supreme Court followed a unifying thesis compatible with minimum harmonisation and took the clear view that as a matter of EU law the existence of grounds for an action in damages based on the Remedies Directive requires the existence of a 'sufficiently serious breach' of EU public procurement law. The UK Supreme Court explicitly ruled out any inconsistency between this approach and other case law of the CJEU, in particular Strabag, on the basis that the cases are not incompatible and, importantly, that the CJEU in Spijker was aware of the recent decision in [Strabag], cited it . . and clearly did not consider it in any way inconsistent with what [it] said about the general applicability of the Francovich conditions'. ${ }^{66}$ Importantly, the UK Supreme Court took no issue with the possibility for more generous domestic grounds for actions for damages. ${ }^{67}$ On the whole, the UK Supreme Court considered that 'there is no uncertainty or confusion in the Court of

62 Whether this is compatible with a unifying thesis or with a separation thesis, or neither of them, remains unclear, but this aspect of the discussion exceeds the scope of this article.

63 Nuclear Decommissioning Authority (n 9) as per Lord Mance, with Lady Hale and Lords Neuberger, Sumption and Carnwath agreeing.

64 Ibid per Lord Mance, at [23], emphasis added.

65 Ibid at [25], emphasis added.

66 Ibid at [24], emphasis added.

67 Although it eventually decided that this was not the case in relation to the Public Contract Regulations 2006; see Nuclear Decommissioning Authority (n 9) per Lord Mance, at [37], with which I also agree. 
Justice's case law, and that [it is safe to rely] on the clear language and ruling in Spijker as settling the position, whatever may have been previous doubts or differences of view at national level'. 68

\section{Conclusion}

The controversy underpinning the Fosen-Linjen saga is ultimately reflective of discussions about the interrelation between the Remedies Directive and the more general principle of state liability for breaches of EU/EEA. The CJEU had unequivocally established in 2010 that the Remedies Directive 'gives concrete expression to the principle of State liability for loss and damage caused to individuals as a result of breaches of EU law for which the State can be held responsible'. ${ }^{69}$ Therefore, only 'sufficiently serious breaches' of EU/EEA procurement law give rise to liability in damages, provided the other requirements are present. This should have put the discussion to rest, as forcefully argued by the UK Supreme Court in 2017. ${ }^{70}$ However, as Fosen-Linjen I evidenced, the debate lingered on. The reversal of the EFTA Court's view in Fosen-Linjen II should serve to bury the issue. However, this may encounter some additional resistance. Therefore, the CJEU would be well advised to (re)confirm the unitary thesis enshrined in Spijker at the earliest opportunity to avoid any perpetuation of this debate in the context of EU/EEA public procurement law.

\section{Postscript}

The Norwegian Supreme Court delivered its judgment in the so-called Fosen-Linjen case on 27 September 2019 (HR-2019-1801-A). As a general approach, the Norwegian Supreme Court followed the unitary thesis reflected in Fosen-Linjen II. However, it granted the appellant compensation for the negative interest, but not for the positive interest. This raises a number of interpretive issues concerning the boundary between the liability threshold and the analysis of causation in claims for damages due to a breach of procurement rules. The interested reader will find detailed analysis in D S Lund, 'The Fosen-Linjen Saga - a Norwegian Perspective' (2019) European Procurement and Public Private Partnership Law Review (forthcoming).

Ibid at [26], with reference to A Collins, 'Damages in Public Procurement - An Illusory Remedy?', in K Bradley, N Travers and A Whelan (eds), Of Courts and Constitutions. Liber Amicorum in Honour of Nial Fennelly (Hart 2014) 339.

69 Spijker (n 8) para 87, emphasis added.

70 Nuclear Decommissioning Authority (n 9). 